
U G L A F O R U M I N M E D I G A L S G I E N G E S

Victor E. HaLl, Editor

Martha Bascopé-Espada, Assistant Editor

\begin{tabular}{ll}
\multicolumn{2}{c}{ EDrrorial BOARD } \\
Forrest H. Adams & William P. Longmire, Jr. \\
Mary A. B. Brazier & H. W. Magoun \\
Carmine D. Clemente & C. D. O'Malley \\
Louise M. Darling & Sidney Roberts \\
Morton I. Grossman & Emil L. Smith \\
\multicolumn{2}{c}{ Reidar F. Sognnaes }
\end{tabular}

UNIVERSITY OF CALIFORNIA, LOS ANGELES 


\section{PATHOPHYSIOLOGY OF CONGENITAL HEART DISEASE}





\section{UCLA FORUM IN MEDICAL SCIENCES}

NUMBER 10

\section{PATHOPHYSIOLOGY OF CONGENITAL HEART DISEASE}

Proceedings of a Conference held July, 1967

Sponsored by the Division of Pediatric Cardiology, Department of Pediatrics, University of California, Los Angeles, School of Medicine and the American College of Cardiology

EDITORS

Forrest H. Adams, H. J. C. Swan and Victor E. Hall

UNIVERSITY OF CALIFORNIA PRESS

BERKELEY, LOS ANGELES AND LONDON 
CITATION FORM

Adams, F. H., Swan, H. J. C., and Hall, V. E. (Eds.),

Pathophysiology of Congenital Heart Disease. UCLA Forum Med. Sci. No. 10, Univ. of California Press, Los Angeles, 1970

University of California Press

Berkeley and Los Angeles, California

(C) 1970 by The Regents of the University of California

Standard Book Number 520-01630-0

Library of Congress Catalog Number 69-16626

Printed in the United States of America 


\title{
PARTICIPANTS IN THE CONFERENCE
}

\author{
Forrest H. Adams, Chairman and Editor \\ Division of Pediatric Cardiology \\ UCLA School of Medicine \\ Los Angeles, California 90024
}

H. J. C. Swan, Co-Chairman and Co-Editor

Department of Cardiology

Cedars-Sinai Medical Center

Los Angeles, California 90029

Victor E. Hall, Co-Editor

Division of Pediatric Cardiology and Brain Information Service

UCLA School of Medicine

Los Angeles, California 90024

\author{
Nicholas S. Assali \\ Departments of Obstetrics-Gynecology and Physiology \\ UCLA School of Medicine \\ Los Angeles, California 90024
}

Allan J. Brady

The Los Angeles County Heart Association Research Laboratory and Department of Physiology

UCLA School of Medicine

Los Angeles, California 90024

Eugene Braunwald ${ }^{\circ}$

Cardiology Branch, National Heart Institute

National Institutes of Health

Bethesda, Maryland 20014

Robert L. DeHaAN

Department of Embryology

Carnegie Institution of Washington

Baltimore, Maryland 21210

- Present affiliation: Department of Medicine, University of California, San Diego, School of Medicine, La Jolla, California 92037. 
Donald T. Desicets

Department of Radiology

UCLA School of Medicine

Los Angeles, California 90024

\author{
S. Evans Downing \\ Department of Pathology \\ Yale University School of Medicine \\ New Haven, Connecticut 06510
}

George C. Emmanounides

Division of Pediatric Cardiology, UCLA School of Medicine and Department of Pediatric Cardiology and Neonatology

Harbor General Hospital

Torrance, California 90509

\title{
Dean L. Frankitin
}

Biomedical Engineering, Scripps Clinic and Research Foundation and University of California, San Diego, School of Medicine

La Jolla, California 92037

\section{WILLIAM F. FrIEDMAN *}

National Heart Institute

National Institutes of Health

Bethesda, Maryland 20014

Ira H. Gessner

Department of Pediatrics

University of Florida College of Medicine

Gainesville, Florida 32601

Stanley J. GoldBerg

Division of Pediatric Cardiology

UCLA School of Medicine

Los Angeles, California 90024

Paul H. Heintzen

Universitäts-Kinderklinik

University of Kiel

23 Kiel, West Germany

Paul G. Hugenholtz $\dagger$

Children's Hospital Medical Center

and Department of Pediatrics, Harvard Medical School

Boston, Massachusetts 02115

\footnotetext{
- Present affliation: Division of Pediatric Cardiology, University of California, San Diego, School of Medicine, La Jolla, California 92037.

$\uparrow$ Present affliation: Department of Cardiology, University Hospital, University of Rotterdam, Rotterdam, The Netherlands.
} 
Alexander Kolin

Department of Biophysics

UCLA School of Medicine

Los Angeles, California 90024

GLenN A. Langer

Departments of Medicine and Physiology

UCLA School of Medicine

I .os Angeles, California 90024

C. Walton Lillehei

Department of Surgery

University of Minnesota Medical School

Minneapolis, Minnesota

LEONARD M. LINDE

Division of Pediatric Cardiology

UCLA School of Medicine

Los Angeles, California 90024

JERE H. Mitchell

The Pauline and Adolph Weinberger Laboratory for Cardiovascular Research

Department of Internal Medicine

University of Texas Southwestern Medical School

Dallas, Texas 75235

Wilfried F. H. M. Mommaerts

Department of Physiology

and the Los Angeles County Heart Association

Cardiovascular Research Laboratory

UCLA School of Medicine

Los Angeles, California 90024

Arthur J. Moss

Division of Pediatric Cardiology

UCLA School of Medicine

Los Angeles, California 90024

JoHn F. Murray

Department of Medicine and Cardiovascular Research Institute

University of California San Francisco Medical Center

San Francisco, California 94122

Peter Osypka

Department of Bio-Engineering and Universitäts-Kinderklinik

University of Kiel

23 Kiel, West Germany 
Abraham M. Rudolph

Cardiovascular Research Institute and Department of Pediatrics

University of California San Francisco Medical Center

San Francisco, California 94122

Herbert D. RUTtenberG ${ }^{\circ}$

Division of Pediatric Cardiology

UCLA School of Medicine

Los Angeles, California 90024

Ronald H. Selvester

ECG and Biomathematics Research Group and Cardiology Department

Rancho Los Amigos Hospital

Downey, California 90242

and University of Southern California School of Medicine

Los Angeles, California

Norman J. Sissman

Division of Pediatric Cardiology

Stanford University School of Medicine

Palo Alto, California

EDMUND H. SONNENBLICK

Cardiology Branch, National Heart Institute

Bethesda, Maryland 20014

and Cardiovascular Unit, Peter Bent Brigham Hospital

Boston, Massachusetts 02115

Madison S. SPaCH

Division of Pediatric Cardiology

Duke University School of Medicine

Durham, North Carolina 27706

Norman S. TALner

Department of Pediatrics

Yale University School of Medicine

and Yale-New Haven Hospital

New Haven, Connecticut 06510

Robert L. VAN CitTers

Departments of Physiology and Biophysics

University of Washington School of Medicine

Seattle, Washington 98105

- Present affliation: Department of Pediatric Cardiology, University of Utah College of Medicine, Salt Lake City, Utah 84112. 
LODEWYK H. S. VAN Muerop

Department of Pediatrics and Human Development Center

University of Florida College of Medicine

Gainesville, Florida 32601

HOMER R. WARner

Department of Biophysics and Bioengineering

University of Utah College of Medicine

Salt Lake City, Utah 84112

EARL H. WoOD

Section of Physiology

Mayo Clinic and Mayo Foundation

Rochester, Minnesota 55901 